\title{
Venomous mollusks: the risks of human accidents by Conus snails (Gastropoda: Conidae) in Brazil
}

\author{
Moluscos peçonhentos: riscos de acidentes em humanos pelo molusco Conus \\ (Gastrópode: Cunidae) in Brazil
}

\author{
Vidal Haddad Junior, ${ }^{1,2}$, João Batista de Paula Neto ${ }^{3}$ and Válter José Cobo ${ }^{4}$
}

\begin{abstract}
Mollusks of the genus Conus present a venomous apparatus composed of radulae, a chitin structure linked to glands, which injects potent neurotoxic peptides, causing serious human envenomation and even death, associated with the blockage of certain receptors and muscular paralysis. No reported envenomation has occurred in Brazil, but certain populations are at risk of accidents.
\end{abstract}

Key-words: Conus. Venomous animals. Venomous mollusks. Human envenoming. Brazil.

\section{RESUM0}

Os moluscos do gênero Conus apresentam um aparato venenoso composto de uma rádula quitinosa ligada a glândulas de peçonha, causando envenenamentos humanos graves e mesmo óbitos pela ação neurotóxica indutora do bloqueio de vários receptores e paralisia muscular. Não há casos descritos de envenenamento no país, mas determinadas populações correm risco de acidentes.

Palavras-chaves: Conus. Animais peçonhentos. Moluscos venenosos. Envenenamentos humanos. Brasil.

Mollusks include some of the most well-known invertebrates. Phyllum species present a specialized chitin tooth-like feeding structure (the radulae) that can grind through the shells of other animals ${ }^{19}$. The class Gastropoda includes marine, terrestrial and freshwater snails, limpets, nudibranchs, slugs and abalones.

\section{CONUS SNAILS}

The most specialized gastropods may be the cone snails, genus Conus, in which the radulae is reduced to a few isolated venom-injecting teeth, the so-called toxoglossate radulae, that are linked to venomous glands. The harpoon-like teeth are discharged from the end of a long proboscis that can be ejected rapidly to capture its prey (Figures 1 and 2). The Conus genus presents a unique spiraled shell.

The great majority of cone snails feed on other mollusks and bristle worms. However, some species are piscivorous, presenting the most potent toxins and they can cause fatal envenomation in humans ${ }^{7}{ }^{13}$. The most important piscivorous Conus are present in the Indo-Pacific area, such as $C$. geographus (the species most associated with human deaths), $C$. aulicus, $C$. marmoreus, C. striatus $C$. textile and $C$. tulipa. There are about two dozen Conus species in Brazil and the mostimportantare $C$. centurio, $C$. clench, C. clerii, C. ermineus, $C$. jaspidus, and $C$. regius ${ }^{10}$. Moreover, species like $C$. clerii, $C$. jaspideus and $C$. regius feed actively on marine worms and present active toxins ${ }^{2}$. The worm-eating Conus offer less danger to human beings, but some species that provoke serious accidents are not piscivorous, such as $C$. marmoreus.

\footnotetext{
1. Faculdade de Medicina de Botucatu da Universidade Estadual Paulista, Botucatu, SP. 2. Hospital Vital Brazil do Instituto Butantan, São Paulo, SP, Brazil. 3. Programa de Assistência à AIDS, Moçambique. 4. Departamento de Biologia da Universidade de Taubaté, Taubaté, SP. Address to: Dr. Vidal Haddad Junior. Caixa Postal 557, 18618-000, Botucatu, SP, Brazil.

Telefax: 5514 3882-4922

e-mail: haddadjr@fmb.unesp.br

Recebido para publicação em 20/4/2006

Aceito em 10/8/2006
} 


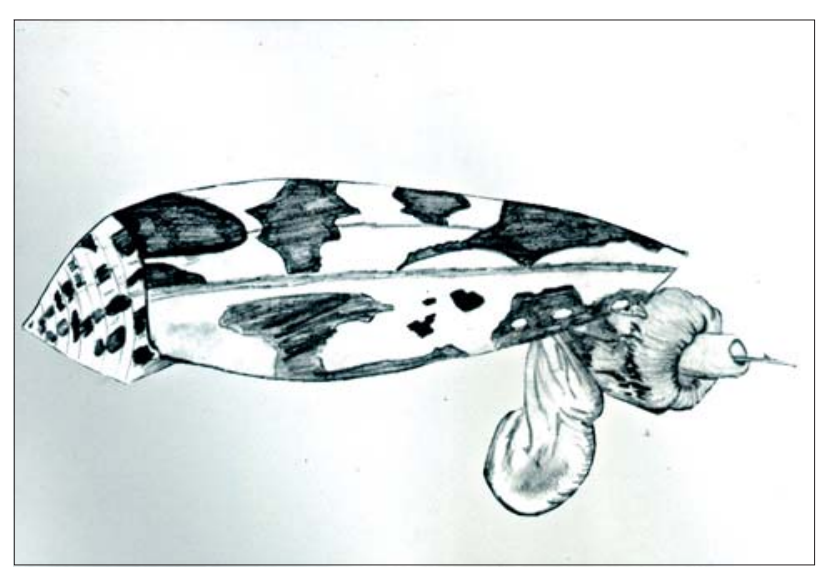

Figure 1 - Conus snail in attack position, showing the proboscis and the radulae, structures capable to envenoming with gravity human beings.

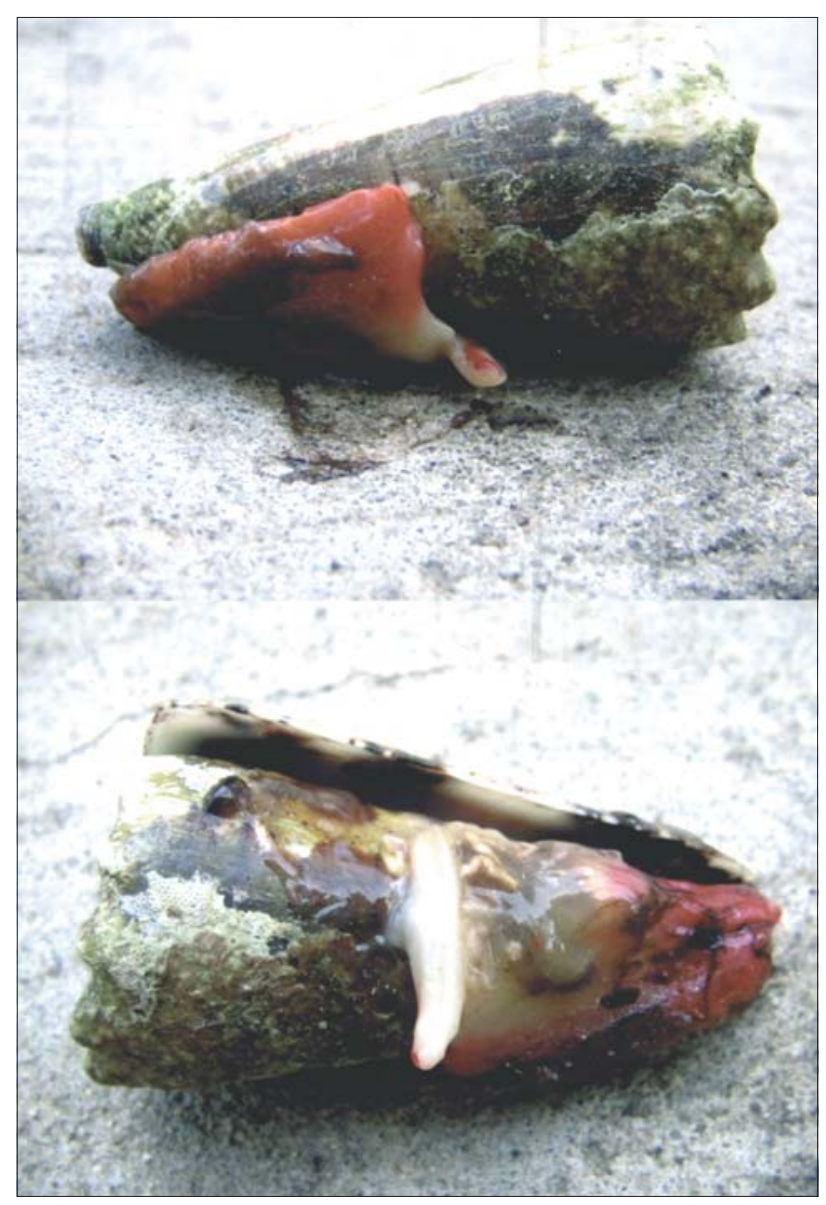

Figure 2 - A live specimen of Conus of Mozambique - Indian Ocean showing the proboscis (probable Conus imperialis).

\section{VENOM ACTION OF THE CONUS SNAILS}

The venom of the Conus species is composed of conotoxins, which are neurotoxins of low molecular weight. Their action is extremely fast, which is compatible with the slowness of the snail in its environment and the consequent difficulty involved in capturing the poisoned prey.

The action of the conotoxins occurs by blockage of muscular and neural receptors ${ }^{7}$. There are two different toxin effects in the venom. The first, the "lightning-strike" effect, causes immediate immobilization of the injected prey through peptides that inhibit voltage-gated sodium channel inactivation, as well as peptides thatblock potassium channels. Together, this combination results in a massive depolarization of any axons in the immediate vicinity of the venom injection site, causing an effect similar to electrocuting the prey. The second effect is achieved more slowly and involves total inhibition of neuromuscular transmission through conopeptides, which act at sites remote from the venom injection site, such as neuromuscular junctions. The motor cabal effect, found in all fish-hunting Conus venoms examined so far, includes peptides that inhibit the presynaptic calcium channels that control neurotransmitter release, the postsynaptic nicotinic receptors, and the sodium channels that underlie the muscle action potential ${ }^{20}$.

Currently, conotoxins are a valuable tool of scientific research, due to the intense pharmacological activity presented by the peptides. One of the drugs in clinical tests is ziconotide, which is a peptide that blocks the neuronal calcium canals with excellent effect in the treatment of chronic and severe painful processes ${ }^{16}$.

\section{CLINICAL ASPECTS OF THE ENVENOMATION}

The exact number of proven deaths caused by envenomation by Conus shells is not known, though about 50 supposed occurrences are cited. Envenomation can simulate other causes of death, like myocardial infarction or cerebral ischemia, and may not always be correctly identified. The index of mortality observed in envenomation by Conus shells reaches $25 \%$.

A typical accidentinvolving Conus shells, initially presents intense burning pain at the site of the sting, which evolves in about one hour to progressive paralysis of the body muscles without other local symptoms or signs. History of contact with the mollusk associated with intense muscular weakness should raise suspicion of an accident. In later phases, the patient can develop palpebral ptosis, blurry vision and speech and deglutition difficulties, unconsciousness and dyspnoea, with possible evolution to respiratory arrest that can be fatal and occurs 40 minutes to 5 hours after the sting 3791213151718 .

In Brazil, three species of Conus of large diameter are potentially dangerous: $C$. regius, $C$. centurio and $C$. ermineus, the last of which is piscivorous ${ }^{311}$. C. ermineus was identified in the Fernando de Noronha Islands ${ }^{6}$, when studies regarding its high toxicity and the potential risk for human envenomation already existed ${ }^{184}$. Currently, however, there is no safe clinical information regarding the species of Conus found in Brazil or the occurrence of possible accidents, although the possibility of envenomation, especially for Biology professionals and shell collectors exists.

Diagnosis of the injuries caused by venomous mollusks is based on clinical observation. There is no antidote for the toxins and severe envenomation should be treated with artificial ventilation, the only effective measure, since no 
available antivenom exists at present ${ }^{15}$. Severity depends on the time passed since envenomation and of the full installation of the manifestations, with some consideration given to the sting site. A lack of medical resources also influences the prognosis. Envenomation by the Conus genus is rare, but it is possible in risk populations and the gastrointestinal and neuromuscular symptoms in patients should not be confused with alimentary poisoning.

\section{REFERENCES}

1. Barbier J, Lamthanh H, Le Gall F, Favreau P, Benoit E, Chen H, Gilles N, Ilan N, Heinemann SH, Gordon D, Menez A, Molgo J. A delta-conotoxin from Conus ermineus venom inhibits inactivation in vertebrate neuronal $\mathrm{Na}(+)$ channels, but not in skeletal and cardiac muscles. Journal of Biological Chemistry 279:4680-4685, 2003.

2. Braga MCV, Konno K, Portaro FC, Freitas JC, Yamane T, Olivera BM, Pimenta DC. Mass spectrometric and high performance liquid chromatography profiling of the venom of the Brazilian vermivorous mollusk Conus regius: feeding behavior and identification of one novel conotoxin. Toxicon 45:113-122, 2005.

3. Cardoso JLC, França FOS, Wen FH, Malaque CMS, Haddad Jr V. Animais peçonhentos no Brasil: Biologia, Clínica e Terapêutica dos Acidentes. Editora Sarvier, São Paulo, 2003.

4. Chierici S, Jourdan M, Figuet M, Dumy P. Synthesis of cis-Pro isomer analogs of delta-Conotoxin EVIA from Conus erminius. A case study of 2,2dimethylthiazolidine as locked cis proline amide bond: synthesis, NMR and molecular modeling studies of a [ small delta] -conotoxin EVIA peptide analog. Organic and Biomolecular Chemistry 2: 2437-2441, 2004.

5. Coltro J. New Species of Conidae from Northeastern Brazil ( Conus bodarti, Conus henckesi, Conus delucai, Conus schirrmeisteri, Conus baiano, Conus cargilei, Conus mauricioi, Conus pseudocardinalis). Strombus, 11, 2004.

6. Costa FHA. Primeiro registro de Conus ermineus Born, 1778 (Gastropoda, Conidae) para 0 Arquipélago de Fernando de Noronha, com alguns comentários sobre sua periculosidade para 0 homem. Anais do XII Encontro Brasileiro de Malacologia, São Paulo, 1991.

7. Cruz LJ, White J. Clinical toxicology of Conus snail stings. In: Meier J, White J, (eds) Clinical Toxicology of Animal Venoms. CRC Press, Boca Raton FL, 1995.

8. Duarte L. Danger from Conus ermineus. In: Burnay LP, Monteiro AA. Seashells from Cape Verde Islands. by the authors, Lisbon, 1977.

9. Flecker $\mathrm{H}$. Cone shell poisoning, with report of a fatal case. Medical Journal of Australia 1: 464-466, 1936.

10. Gomes RC. Família Conidae no Brasil. http;//www.conchasbrasil.org.br/ ata_030510.asp. Acessed in 05/10/2005, 2001.

11. Guest RR. Observations on the feeding behavior of Conus aurantius Hwass in Bruguiere, 1792 and Conus ermineus Born, 1778, collected from Bonaire, Netherlands Antilles. Veliger 19: 204-206, 1976.

12. Haddad Jr V. Atlas de animais aquáticos perigosos do Brasil: guia médico de identificação e tratamento (Atlas of dangerous aquatic animals of Brazil: a medical guide to identification and treatment). Editora Roca, São Paulo, 2000.

13. Kohn AJ. Piscivorous gastropods in the genus Conus. Proceedings of the National Academy of Sciences USA 42:168-171, 1956.

14. Kohn AJ. Recent cases of human injury due to venomous marine snails of the genus Conus. Hawaii Medical Journal 17:528-532, 1958.

15. Mebs D. Venomous and Poisonous Animals - a Handbook for Biologists, Toxicologists and Toxinologists, Physicians and Pharmacists. Boca Raton, CRC Press, 2002.

16. Miljanich GP. Ziconotide: neuronal calcium channel blocker for treating severe chronic pain. Current Medicinal Chemistry 11: 3029-3040, 2004.

17. Petrauskas LE. A case of conus shell poisoning by "bite" in Manus Island. New Guinea Medical Journal 1:67-68, 1955.

18. Rice RD, Halstead BW. Report of a fatal cone shell sting by Conus geographus Linnaeus. Toxicon 5:223-224, 1968.

19. Ruppert EE, Fox RS, Barnes RD. Invertebrate Zoology, a Functional Evolutionary Approach. $7^{\text {th }}$ edition. Brooks/Cole-Thomson Learning. Belmont, CA, 2003.

20. Terlau H, Olivera BM. Conus venoms: a rich source of novel ion channeltargeted peptides. Physiological Reviews 84: 41-68, 2004. 